\title{
Migratory behaviour and habitat use by American eels Anguilla rostrata as revealed by otolith microchemistry
}

\author{
B. M. Jessop ${ }^{1, *}$, J.-C. Shiao ${ }^{2}$, Y. Iizuka ${ }^{3}$, W.-N. Tzeng ${ }^{2}$ \\ ${ }^{1}$ Department of Fisheries and Oceans, Bedford Institute of Oceanography, PO Box 1006, Dartmouth, Nova Scotia \\ B2Y 4A2, Canada \\ ${ }^{2}$ Department of Zoology, College of Science, National Taiwan University, Taipei, Taiwan 10617, ROC \\ ${ }^{3}$ Institute of Earth Sciences, Academia Sinica, Nankang, Taipei, Taiwan 11529, ROC
}

\begin{abstract}
The environmental history of American eels Anguilla rostrata from the East River, Nova Scotia, was investigated by electron microprobe analysis of the Sr:Ca ratio along transects of the eel otolith. The mean $( \pm \mathrm{SD}) \mathrm{Sr}$ :Ca ratio in the otoliths of juvenile American eels was $5.42 \times 10^{-3} \pm 1.22 \times$ $10^{-3}$ at the elver check and decreased to $2.38 \times 10^{-3} \pm 0.99 \times 10^{-3}$ at the first annulus for eels that migrated directly into the river but increased to $7.28 \times 10^{-3} \pm 1.09 \times 10^{-3}$ for eels that had remained in the estuary for $1 \mathrm{yr}$ or more before entering the river. At the otolith edge, Sr:Ca ratios of $4.0 \times 10^{-3}$ or less indicated freshwater residence and ratios of $5.0 \times 10^{-3}$ or more indicated estuarine residence. Four distinct but interrelated behavioural groups were identified by the temporal changes in $\mathrm{Sr}: \mathrm{Ca}$ ratios in their otoliths: (1) entrance into freshwater as an elver, (2) coastal or estuarine residence for 1 yr or more before entering freshwater, and, after entering freshwater, (3) continuous freshwater residence until the silver eel stage and (4) freshwater residence for $1 \mathrm{yr}$ or more before engaging in periodic, seasonal movements between estuary and freshwater until the silver eel stage. Small $(<70 \mathrm{~mm}$ total length), highly pigmented elvers that arrived early in the elver run were confirmed as slow growing age-1 juvenile eels. Juvenile eels that remained $1 \mathrm{yr}$ or more in the estuary before entering the river contributed to the production of silver eels to a relatively greater extent than did elvers that entered the river during the year of continental arrival.
\end{abstract}

KEY WORDS: American eel $\cdot$ Otolith $\cdot$ Strontium:calcium ratio $\cdot$ Environmental history

\section{INTRODUCTION}

American eels Anguilla rostrata exhibit high temporal and geographic variability in many life history traits (Tesch 1977, Helfman et al. 1987, Oliveira 1999). Such plasticity in biological characteristics and environmental requirements may be fundamental to the success of this panmictic and semelparous species. It spawns in the Sargasso Sea and ranges geographically from Venezuela to Greenland. The Gulf Stream distributes

*E-mail: jessopb@mar.dfo-mpo.gc.ca the leaf-like larvae, leptocephali, along the Atlantic coast of North America. The larvae metamorphose to glass eels in continental waters and migrate inshore to coastal waters, estuaries and streams, where they become pigmented elvers. Most American eel elvers probably migrate into freshwater, as do Japanese and European eel elvers. A variable but unknown proportion of elvers may remain in coastal and estuarine waters for times ranging from 1 to several years, or for their entire juvenile life, before beginning sexual maturation and the spawning migration (Smith \& Saunders 1955, Tsukamoto et al. 1998, Tzeng et al. 2000, in press). 
Patterns in the strontium (Sr) to calcium (Ca) ratio of otoliths, in combination with age data, have been used to elucidate the environmental history of fish, particularly the habitat use and seasonal migration for various fishes, including Anguilla spp. (Otake et al. 1994, Tzeng \& Tsai 1994, Tzeng 1996, Tzeng et al. 1997, 1999, 2000, in press, Secor 1999, Secor \& Rooker 2000). The variability in migratory behaviours associated with habitat selection has recently been investigated for leptocephali metamorphosing to glass eels over the continental shelf (Cheng \& Tzeng 1996, Wang \& Tzeng 1998, 2000, Arai et al. 2000, Shiao et al. 2001) and for estuarine- and freshwater-resident yellow and silver eels (Tzeng et al. 1997, 2000, in press). Otolith microconstituents are measured precisely along a radius between the nucleus and edge of the otolith so as to reconstruct a chronology of environmental conditions related to age and life stage. A positive relationship exists between otolith $\mathrm{Sr}$ :Ca ratio and ambient salinities among marine, estuarine and freshwater fishes (Tzeng 1996, Kawakami et al. 1998, Secor \& Rooker 2000).

Runs of juvenile eels of varying age, based upon their size composition, into and up rivers during spring are well known, but autumnal estuarine-to-freshwater migrations and spring freshwater-to-estuary migrations of juvenile American eels may also occur (Smith \& Saunders 1955, Medcof 1969). Upstream migrations of 450 to 1200 juvenile eels of about 70 to $200 \mathrm{~mm}$ total length (TL) occurred concurrent with and following the annual elver run (elvers are typically 50 to $70 \mathrm{~mm}$ TL; Jessop 1998) into the East River, Chester, Nova Scotia, Canada, between 1996 and 2000 (e.g. Jessop 1997). The age composition and residence history of these juveniles is uncertain. We hypothesise that the eel stock within an estuary and associated river watershed is composed of 1 or more of the following behavioural groups: (1) coastal or estuarine resident, (2) entrance to freshwater as an elver, (3) coastal or estuarine resident for $1 \mathrm{yr}$ or more before entering freshwater as a juvenile eel, and, after freshwater entrance, (4) continuous residence in freshwater until exiting as a silver eel and (5) freshwater resident for 1 yr or more before migrating periodically and irregularly between the river and estuary until exiting as a silver eel.

In the absence of definitive age information, size and pigmentation may not always be sufficient to distinguish elvers from small juveniles. Jessop (1998) hypothesised that the elver-sized (less than about $70 \mathrm{~mm}$ ), heavily pigmented eels early in the run are small juveniles rather than elvers that have pigmented particularly rapidly.

The observed annual spring migration of juvenile eels of various ages from the estuary to the river should be evident in the otolith environmental history of silver eels from the river, consistent with the observations by Smith \& Saunders (1955) and Medcof (1969) of seasonal migrations between river and estuary. In addition, the proportion of silver eels showing a history of river entrance as an elver or as a juvenile should indicate the relative importance of each group's contribution to the development of the river stock. The high mortality rate $(M)$ of elvers during their first summer in freshwater $(M>0.99$; Jessop 2000) and the size of the juvenile run lead to the hypothesis that a substantial proportion of silver eels would show evidence of a period of estuarine residence as a juvenile prior to entering the river.

This study examined the $\mathrm{Sr}$ and $\mathrm{Ca}$ deposition patterns in the otoliths of American eels in relation to their age and migratory history (upstream-migrant juveniles, downstream-migrant silver eels) for evidence in support of hypotheses that (1) a complex variety of migration and habitat residence patterns occurs; (2) elver-sized, heavily pigmented eels early in the run are small juveniles; and (3) the observed pattern of juvenile eel migration is evident in the otolith environmental history of silver eels.

\section{MATERIALS AND METHODS}

Study area. The East River (near Chester, Nova Scotia) has a watershed area of $134 \mathrm{~km}^{2}$ and drains into Mahone Bay, which is located slightly south of the midpoint along the Atlantic coast of Nova Scotia (Fig. 1). A small falls $(0.6 \mathrm{~m})$ occurs at the outlet of the river just upstream of the high-tide mark. The river ranges in $\mathrm{pH}$ from 4.7 to 5.0 ; conductivity averages $24 \mu \mathrm{mho} \mathrm{cm}^{-1}$ (Watt et al. 1995). The Sr:Ca ratio of the river water at site B of Fig. 1 was measured as $5.6 \times 10^{-3}$ in April 2001. River water temperature ranges from about $1-2^{\circ} \mathrm{C}$ in the winter to $23-25^{\circ} \mathrm{C}$ in the summer. River discharge ranges from $<5 \mathrm{~m}^{3} \mathrm{~s}^{-1}$ during the summer to perhaps $35 \mathrm{~m}^{3} \times \mathrm{s}^{-1}$ during the spring flood.

The main branch of the East River (East Branch) was limed because it had a slightly higher natural $\mathrm{pH}$ (about 5.0) than did the Canaan River tributary (4.6 to 4.7 ) and would require less lime to attain a desired $\mathrm{pH}$ (Watt \& White 1992, Watt et al. 1995). Four lakes (about $53 \%$ of the total watershed lake area) in the East Branch had about $350 \mathrm{t}$ of powdered calcite applied annually between 1986 and 1996 (Watt \& White 1992). The calcite dissolution rate during the first year following application was about $35 \%$, and large amounts of calcite remained in the lakes that were limed. The lowermost lake that was limed is $11.6 \mathrm{~km}$ from the river mouth. The Sr:Ca ratio of the water in the East River upriver of the junction with the Canaan River averaged $4.1 \times 10^{-3}$ in July 2001. The Canaan River and Barrys 




Fig. 1. Maps of the East River (Chester, Nova Scotia, Canada) showing location along the Atlantic coast of Nova Scotia, tributary rivers and elver trap sites at (A) river mouth and (B) Highway 103 culvert on main stem 
Brook tributaries contain about $47 \%$ of the watershed lake area and were not limed. The Canaan River has low calcium concentrations (mean $930 \mu \mathrm{g} \mathrm{l}^{-1}$ ) and little buffering capacity (alkalinity $0.0 \mathrm{ppm}$ ) with marginally better conditions in the East Branch. After 5 yr of liming, $\mathrm{pH}$ values in the East Branch increased from about 5.5 to 6.7 but have since returned to previous levels.

The salinity in Mahone Bay about $2 \mathrm{~km}$ from the river mouth varies seasonally and with depth from $\sim 27$ to $31.5 \%$ (M. Dadswell, Acadia University, Wolfville, NS, pers. comm.). In general, winter surface (0 to $60 \mathrm{~m}$ ) salinities in the coastal zone are 31 to $32 \%$ and summer salinities are 30 to $31 \%$. Water temperatures in the East River estuary are about -1 to $2{ }^{\circ} \mathrm{C}$ during winter and rise to about 18 to $20^{\circ} \mathrm{C}$ during the summer but are often in the range 12 to $17^{\circ} \mathrm{C}$. The estuary is well mixed, with a maximum tidal range of $\sim 2 \mathrm{~m}$ and an average range of $1.5 \mathrm{~m}$.

Sample collection. Length, weight, pigmentation stage and sex (from silver eels) were obtained from elvers, juvenile or yellow eels and silver eels randomly collected from the East River (Table 1). Otoliths were removed for age determination and microchemistry analysis. Elvers are defined here as young-of-the-year (YOY) or age-0 eels with pigmentation stage from glass eel to fully pigmented (stage VIB of Elie et al. 1982 or stage 7 of Haro \& Krueger 1988). Although the term juvenile eel includes elvers, the term juvenile eel in most contexts refers to larger, older (yellow) eels prior to the start of sexual maturation (silvering) and migration to the sea to spawn.

TLs were measured fresh, after anaesthetisation in MS-222, to 0.1 for eels $<100$ and to $1.0 \mathrm{~mm}$ for larger eels. Weights were measured to $0.01 \mathrm{~g}$ for eels less than $10 \mathrm{~g}$ and to $0.1 \mathrm{~g}$ for larger eels. Elver pigmentation was classified as stages 1 to 7 , following Haro \& Krueger (1988). Older juvenile eels, often readily identified as yellow eels, were classified as stage 8, an extension of the system used by Haro \& Krueger (1988) and equivalent to stage VII of Elie et al. (1982). Elvers and juvenile eels were then preserved in $95 \%$ ethanol. The length distributions of juvenile eels selected for otolith extraction from the different sample groups were matched with the length distributions of those groups when freshly measured. The matched cases were used to develop a linear conversion equation for application to other cases: $\mathrm{PL}=3.681+0.908 \mathrm{FL}$, where $\mathrm{PL}$ is preserved length and FL is fresh length in $\mathrm{mm}$ over the range from 60 to $180 \mathrm{~mm}\left(\mathrm{n}=36, \mathrm{r}^{2}=0.998\right.$, $\mathrm{p}<0.001)$.

The silver eels were frozen fresh and stored in a sealed bag, then thawed prior to length measurements. American eels of about $400 \mathrm{~mm}$ length shrink by about $1.6 \%$ after freezing and thawing (W. Morrison, Chesapeake Bay Biological Laboratory, Solomons, MD, USA, pers. comm.), while European eels of similar size shrink about $2.5 \%$ in length and $2.7 \%$ in weight (Wickstrom 1986). The sex of the silver eels was evaluated macroscopically and later compared with the generalisation that male silver eels are less than $400 \mathrm{~mm}$ long (Krueger \& Oliveira 1997). The heads were then removed and preserved in 95\% ethanol for later removal of the otoliths. Proctor \& Thresher (1998) found little difference between preservation methods such as freezing and ethanol immersion on otolith $\mathrm{Ca}$ concentration, and variability in $\mathrm{Sr}: \mathrm{Ca}$ ratio was due largely to variability in Sr concentration.

Four groups of eels were examined (Table 1):

- Group 1-upstream-migrant juvenile eels collected from elver traps situated just upstream of the head of tide between May 5 and June 19, 2000 (Site A, Fig. 1). Up to 6 eels, as available, were collected for each $5 \mathrm{~mm}$ length interval between 70 and $150 \mathrm{~mm}$ or more. These eels were fully pigmented (stage 8), with the larger eels appearing as yellow eels.

- Group 2-upstream-migrant juvenile (pigment stage 8) eels collected by elver trap just upstream of the head of tide (Site A, Fig. 1) between May 5 and 22

Table 1. Sample data for microchemistry analysis of otoliths of American eels collected from the East River, Nova Scotia. Undiff.: undifferentiated gonads

\begin{tabular}{|c|c|c|c|c|c|c|c|c|c|c|}
\hline \multirow{2}{*}{ Group } & \multirow{2}{*}{$\begin{array}{l}\text { Sampling } \\
\text { late } \mathrm{mm} / \mathrm{dd} / \mathrm{yy}\end{array}$} & \multirow{2}{*}{ Site } & \multirow[t]{2}{*}{ Stage } & \multirow[t]{2}{*}{ Sex } & \multirow[t]{2}{*}{$\mathrm{n}$} & \multirow[t]{2}{*}{ Age (yr) } & \multicolumn{2}{|c|}{ Length (mm) } & \multicolumn{2}{|c|}{ Weight (g) } \\
\hline & & & & & & & Mean \pm SD & Range & Mean $\pm \mathrm{SD}$ & Range \\
\hline 1 & $\begin{array}{l}05 / 05 / 00- \\
06 / 19 / 00\end{array}$ & $\begin{array}{l}\text { River } \\
\text { mouth }\end{array}$ & Juvenile & Undiff. & 29 & $1-4$ & $101.9 \pm 25.84$ & $72.4-180.1$ & $1.42 \pm 1.650$ & $0.29-8.2$ \\
\hline 2 & $\begin{array}{l}05 / 05 / 00- \\
05 / 22 / 00\end{array}$ & $\begin{array}{l}\text { River } \\
\text { mouth }\end{array}$ & Juvenile & Undiff. & 8 & 1 & $66.0 \pm 2.94$ & $62.0-69.8$ & $0.25 \pm 0.068$ & $0.14-0.32$ \\
\hline 3 & 06/28/00 & $\begin{array}{l}1.3 \mathrm{~km} \\
\text { upriver }\end{array}$ & $\begin{array}{l}\text { Elver/ } \\
\text { Juvenile }\end{array}$ & Undiff. & 19 & $1-2$ & $70.9 \pm 6.05$ & $63.0-84.0$ & $0.33 \pm 0.108$ & $0.19-0.58$ \\
\hline \multirow[t]{2}{*}{4} & $\begin{array}{l}\text { 09/28/98- } \\
09 / 30 / 98\end{array}$ & $\begin{array}{l}1.3 \mathrm{~km} \\
\text { upriver }\end{array}$ & Silver $^{\mathrm{a}}$ & $\mathrm{m}$ & 35 & $10-25$ & $355 \pm 18.0$ & $326-412$ & $78.9 \pm 10.04$ & $62.7-115.2$ \\
\hline & & & & $\mathrm{f}$ & 27 & $11-29$ & $468 \pm 86.6$ & $378-740$ & $207.6 \pm 176.81$ & $92.6-882.2$ \\
\hline
\end{tabular}


2000 , that were $<70 \mathrm{~mm}$ long, i.e. the size of larger elvers (Jessop 1998).

- Group 3-upstream-migrant juvenile eels collected on June 28, 2000, from elver traps located $1.3 \mathrm{~km}$ upstream from the river mouth (Site B, Fig. 1).

- Group 4-downstream-migrant silver eels collected from a weir located $1.3 \mathrm{~km}$ upstream from the river mouth (Site B, Fig. 1) during September 28 to 30, 1998.

Microchemical analysis. The otoliths were prepared for electron probe microanalysis of the weight ratio of Sr:Ca by the methods described in Tzeng et al. (1997). The $\mathrm{Sr}$ and $\mathrm{Ca}$ concentration from the primordium to the otolith edge was measured by an electron probe microanalyser (EPMA; JXA-8800R, JEOL) with a wavelength dispersive spectrometer (WDS). The electron beam was defocused at intervals of approximately $10 \mu \mathrm{m}$ on an area of about $5 \mu \mathrm{m}$ diameter by beam conditions of $15 \mathrm{keV}$ and $3 \mathrm{nA}$. The wavelength dispersive spectrum was measured for $120 \mathrm{~s}$ at peak positions and $20 \mathrm{~s}$ at background positions for $\operatorname{Sr} L \alpha$ and at $20 \mathrm{~s}$ and $10 \mathrm{~s}$ for Ca $K \alpha$. The beam power density of $2.3 \mathrm{~W}$

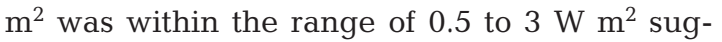
gested by Gunn et al. (1992), and the counting time was sufficient to ensure effective measurement. Calcite $\left(\mathrm{CaCO}_{3} ; \mathrm{NMNH} 136321\right)$ and strontiantite $\left(\mathrm{SrCO}_{3}\right.$ i NMNH R10065) were used as standards. The weight ratio of $\mathrm{Sr}: \mathrm{Ca}$ was calculated after correction with the ZAF method ( $Z$, atomic number effect; $A$, absorption of X-rays within the specimen; F, fluorescence effects; Goldstein et al. 1984). After microprobe analysis, the otoliths were repolished and etched with $5 \%$ EDTA to enhance the annuli (Tzeng et al. 1994). All of the eel otoliths analysed for $\mathrm{Sr}$ :Ca ratio were aged and the distances were measured $(\mu \mathrm{m})$ from the core to various life stage markers: metamorphosis check at the transition from leptocephalus larvae to glass eel, elver check (nominally the freshwater check) at the transition from glass eel to elver and the annuli marking age in years. Mean $( \pm \mathrm{SD})$ otolith $\mathrm{Sr}$ :Ca ratios were calculated at each of the various life stage markers for the juvenile eels of Groups 1 to 3 and the silver eels of Group 4. The Sr:Ca ratio at the otolith edge was assumed to reflect the recent environmental history of the eel and the salinity of its place of capture. The environmental history of each eel was interpreted by examining the temporal pattern of $\mathrm{Sr}$ :Ca ratios along the otolith transect with respect to the estuarine-freshwater decision criteria (see 'Results'), the location of otolith checks representing life history transitions such as the metamorphosis from leptocephalus to glass eel, age as determined from otolith annuli (Jessop 1987, Oliveira 1996), and the location and timing of capture.

\section{RESULTS}

\section{Discrimination of estuarine and freshwater eels by Sr:Ca ratios}

Otolith Sr:Ca ratios varied consistently at various life history stages and in response to different environmental salinities (Fig. 2A). For 56 juveniles of Groups 1 to 3 , the $\mathrm{Sr}$ :Ca ratio averaged $9.82 \pm 2.01 \times 10^{-3}$ at the
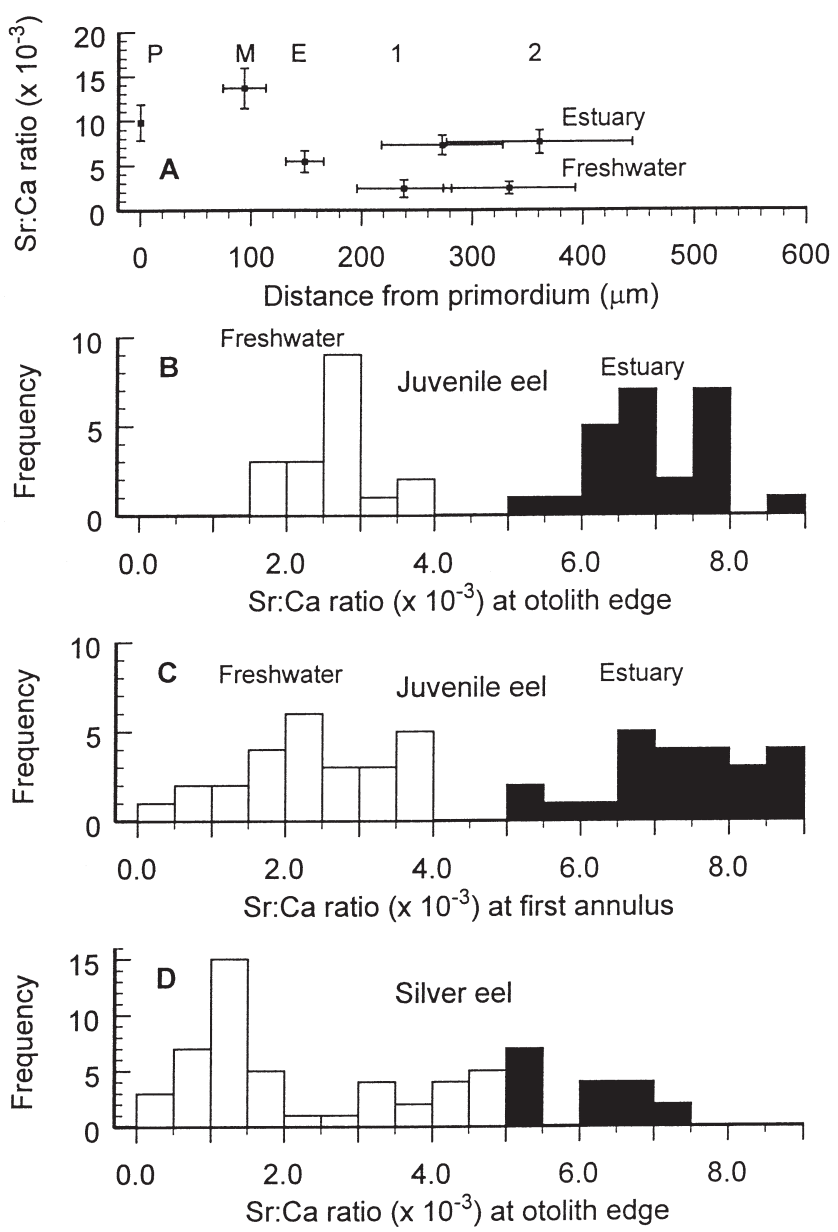

Fig. 2. Anguilla rostrata. (A) Mean $\mathrm{Sr}$ :Ca ratios and distances $( \pm \mathrm{SD})$ along the otolith radius from the primordium $(\mathrm{P})$, metamorphosis check (M), elver check (E), and the first (1) and second (2) annuli for juvenile American eels entering freshwater as an elver and after a period of estuarine residence; (B) frequency distribution of the mean of the final $3 \mathrm{Sr}$ :Ca ratios at the otolith edge for freshwater- $(\mathrm{n}=18)$ and estuarine- $(n=24)$ resident juvenile eels; $(C)$ frequency distribution of Sr:Ca ratios at the first otolith annulus for freshwater- $(n=26)$ and estuarine- $(n=25)$ resident eels; and (D) frequency distribution of the mean of the final $6 \mathrm{Sr}$ :Ca ratios at the otolith edge for downstreammigrating silver eels $(n=64)$ 

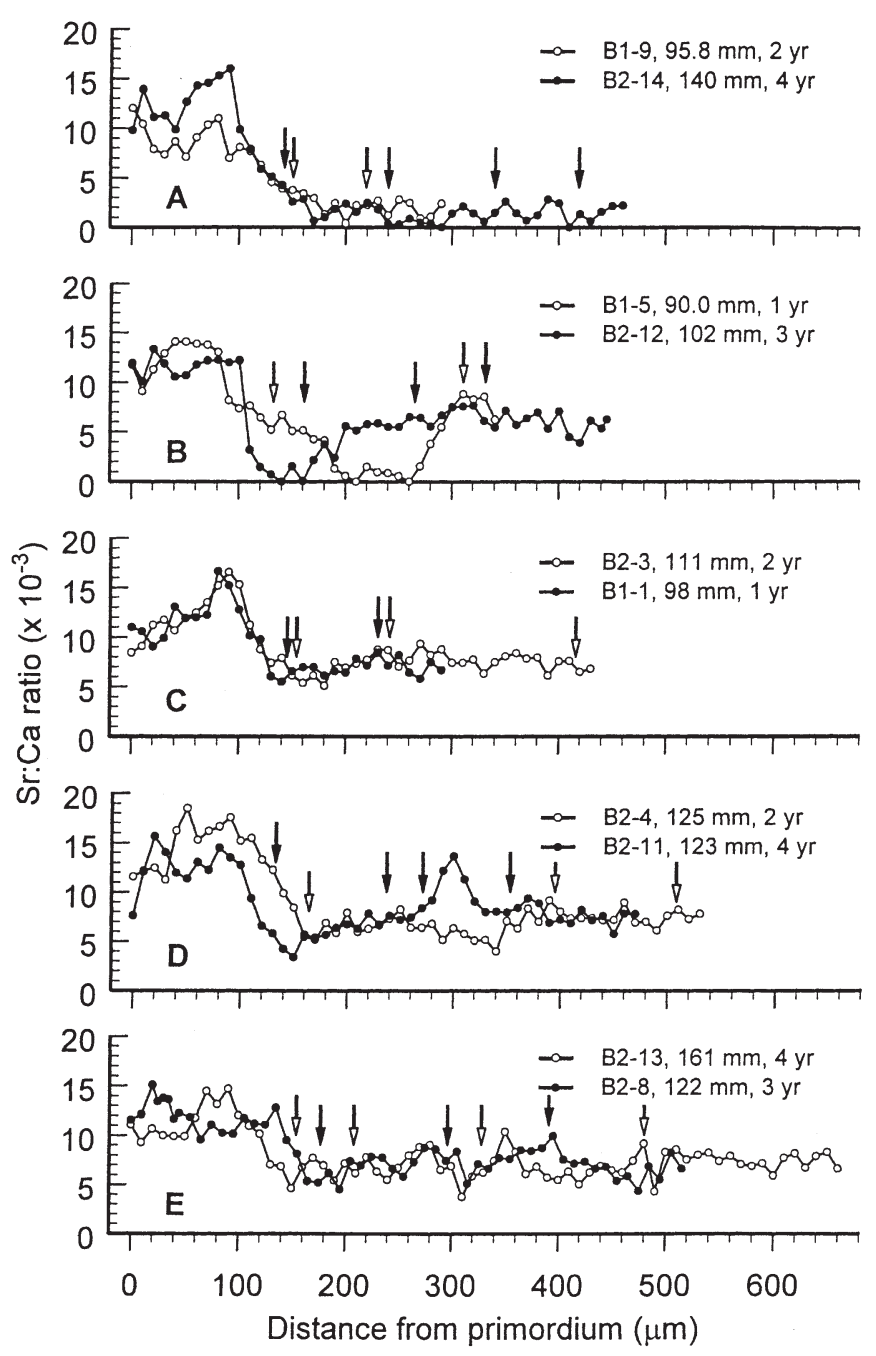

Fig. 3. Anguilla rostrata. Sr:Ca ratio transects along the otolith radius from core to edge of juvenile American eels longer than $70 \mathrm{~mm}$ caught at the mouth of the East River and illustrating various patterns of movement between estuarine and freshwaters: (A) rapid entrance to the river and continuous residence until briefly flushed to tidal waters during the spring freshet; (B) rapid or delayed entrance to the river and return to the estuary; $(\mathrm{C})$ estuarine residence for $1 \mathrm{yr}$ or more before entering the river; $(D, E)$ estuarine residence and movement between low and high salinity areas. The arrows mark the elver check and subsequent annuli. Annuli were not evident at the edges of some otoliths at the time of capture

primordium, $13.63 \times 10^{-3} \pm 2.29 \times 10^{-3}$ at the metamorphosis check and $5.42 \times 10^{-3} \pm 1.22 \times 10^{-3}$ at the elver check ( $\mathrm{P}, \mathrm{M}$ and $\mathrm{E}$, respectively, in Fig. 2A). The $\mathrm{Sr}: \mathrm{Ca}$ ratios of these life history stages did not differ significantly between those eels that entered freshwater as elvers and those that did not (all $\mathrm{p}>0.16$ ). Thus, these eels experienced a similar environmental history before the elver stage. At the first annulus, elvers that migrated directly into the river had significantly lower
Sr:Ca ratios $\left(2.38 \times 10^{-3} \pm 0.99 \times 10^{-3}\right)$ than those that remained in the estuary for a year $\left(7.28 \times 10^{-3} \pm 1.09 \times\right.$ $\left.10^{-3}\right)(t=17.0, \mathrm{df}=1,50, \mathrm{p}<0.001)$. The mean distance from the core of the otolith to the elver check was 148.4 $\pm 4.5 \mu \mathrm{m}$. At age-1, elvers that migrated to the river grew less than those that remained in the estuary, as measured by otolith transect distances (238.4 vs 272.6 $\left.\mu \mathrm{m}_{i} t=2.5, \mathrm{df}=1,50, \mathrm{p}=0.015\right)$. At age- 2 , the growth of the eels in freshwater did not differ from that in the estuary (333.4 vs $360.6 \mu \mathrm{m} ; t=0.7$, $\mathrm{df}=12, \mathrm{p}=0.50$ ), mainly because of the high variability in otolith growth rate at this age and the small sample size.

The grand mean of the means of the final $3 \mathrm{Sr}: \mathrm{Ca}$ ratios at the otolith edge was $6.98 \times 10^{-3}(\mathrm{n}=24$, range $5.38 \times 10^{-3}$ to $8.73 \times 10^{-3}$ ) for upstream-migrant juvenile eels (Group 1, Site A, Fig. 1) and $2.65 \times 10^{-3}$ ( $\mathrm{n}=$ 18 , range $1.74 \times 10^{-3}$ to $3.82 \times 10^{-3}$ ) for juveniles caught upstream later in the year (Group 3, Site B, Fig. 1). For estuarine and freshwater eels, the means of the $\mathrm{Sr}: \mathrm{Ca}$ ratios differed significantly $(t=19.7, \mathrm{df}=1,40, \mathrm{p}<$ 0.001 ) and their ranges did not overlap (Fig. 2C). However, 5 eels from Group 1 were excluded on the basis of patterns in their Sr:Ca ratios between the freshwater check and otolith edge that were more consistent with eels that had spent the past year in the river rather than in the estuary (see following section). One eel from Group 3 was excluded on the basis that its otolith history was consistent with residence in the estuary during the previous year. The $\mathrm{Sr}$ :Ca ratios at the first annulus also comprised 2 groups, ranging from $0.5 \times$ $10^{-3}$ to $3.8 \times 10^{-3}$ and from $5.0 \times 10^{-3}$ to $8.8 \times 10^{-3}$ (Fig. 2B). On the basis of the $\mathrm{Sr}$ : Ca ratios at the otolith edge and the distribution of values at the first annulus, we considered Sr:Ca ratios less than $4.0 \times 10^{-3}$ to indicate freshwater residence and values greater than $5.0 \times 10^{-3}$ to indicate estuarine residence.

The mean Sr:Ca ratios in the final $50 \mu \mathrm{m}$ nearest the edge of otoliths from 64 silver eels ranged from $0.38 \times$ $10^{-3}$ to $7.46 \times 10^{-3}$, with modes at $1.0 \times 10^{-3}$ to $1.5 \times 10^{-3}$ and $5.0 \times 10^{-3}$ to $5.5 \times 10^{-3}$ (Fig. 2D). Of the 9 eels with Sr: Ca ratios between $4.01 \times 10^{-3}$ and $4.99 \times 10^{-3}$, the Sr:Ca ratios declined sharply in 5 eels as the otolith edge was approached.

Four of 14 putative freshwater-resident juvenile eels had 1 probe spot with an $\mathrm{Sr}$ :Ca ratio greater than $4.0 \times$ $10^{-3}$ and less than $5.0 \times 10^{-3}$ out of 78 to 124 spots along the transect from the first annulus to the otolith edge, while 2 eels had 2 disjunct spots. The transition in silver eel otoliths of $\mathrm{Sr}$ Ca ratios to below $4.0 \times 10^{-3}$ to above $5.0 \times 10^{-3}$ was not always sharp, and runs of 2 to 5 intermediate values sometimes occurred. The possible meaning of single spots is discussed later, but 2 or more contiguous spots greater than $4.0 \times 10^{-3}$ or less than $5.0 \times 10^{-3}$ were considered to represent a change in habitat, with intermediate values representing tran- 
sitional conditions. The context of particular $\mathrm{Sr}$ :Ca ratios relative to associated values must be considered. Although the residence classification criteria for $\mathrm{Sr}: \mathrm{Ca}$ ratios is disjunct, the incorporation in the otolith of evidence of a habitat shift is a continuous process. The potential benefits in interpreting the trend of smoothing the data by a moving average with, perhaps, a window width of 3 and the possibility of obscuring important variability were not examined.

\section{Sr:Ca ratios in otoliths of juvenile eels of Groups 1 and 2 at the river mouth}

\section{Group 1}

Upstream-migrant juvenile eels of Group 1 had a mean length of $101.9 \mathrm{~mm}$ (range 72.4 to $180.1 \mathrm{~mm}$ ) and ranged in age from 1 to 4 yr or more (Table 1). Juvenile eel lengths increased with age, but length-at-age was highly variable. The otoliths from 29 eels of Group 1 showed 4 main types of habitat residence and movement patterns: (1) entrance to freshwater as an elver (Fig. 3A, Table 2), either rapidly (Fig. 3B, B2-12) or delayed (Fig. 3B, B1-5); (2) coastal or estuarine residence for $1 \mathrm{yr}$ or more before entering freshwater as a juvenile (Fig. 3C,D,E); and, after river entrance, (3) continuous freshwater residence (Fig. 3A) or (4) a return to the estuary (Fig. 3B). During estuarine residence, juvenile eels may move periodically between zones of higher and lower salinity in the estuary or river mouth (Fig. 3D,E).

Twelve eels ( $41 \%$ ) entered the river directly from the estuary as elvers, of which 5 eels $(17 \%)$ remained in freshwater, as inferred from the pattern of $\mathrm{Sr}$ :Ca ratios in their otoliths (Table 2). After the eels entered freshwater, as determined by the position of the elver check, the Sr:Ca ratio averaged $2.02 \times 10^{-3} \pm 0.51 \times$ $10^{-3}$ (range $0.4 \times 10^{-3}$ to $3.4 \times 10^{-3}$ ) for eel B1-9 and 1.42 $\times 10^{-3} \pm 0.31 \times 10^{-3}$ (range 0.0 to $2.8 \times 10^{-3}$ ) for eel B2-
14 (Fig. 3A). These eels had briefly exited the river for the upper estuary during the spring prior to being caught on the return migration into the river because no evidence of an extended residence in higher salinity water was observed in the $\mathrm{Sr}$ :Ca ratio at the otolith edge following capture.

After entering the upper estuary or river, 7 eels (24\%) returned to the estuary within a year, where they remained for 1 or 2 yr before re-entering the river (Table 2). For example, the Sr:Ca ratio for eel B2-12 (Fig. 3B) was $0.02 \times 10^{-3}$ at the freshwater check, $6.6 \times 10^{-3}$ at the first annulus and $6.2 \times 10^{-3}$ at the otolith edge.

Seventeen eels (59\%) remained in the estuary until entering the river from 1 to 4 yr later (Table 2). Elvers that remained in the estuary following continental arrival, such as eel B1-1 (Fig. 3C), had mean Sr:Ca ratios after the elver check of $6.97 \times 10^{-3} \pm 0.41 \times 10^{-3}$ (range $5.8 \times 10^{-3}$ to $8.4 \times 10^{-3}$ ) and, for eel B2-3, $7.45 \times$ $10^{-3} \pm 0.37 \times 10^{-3}$ (range $5.1 \times 10^{-3}$ to $9.3 \times 10^{-3}$ ). The estuary-resident group showed evidence of movement between areas of high and low salinity (Fig. 3D). For example, fish B2-11 had a Sr:Ca ratio change from 8.5 $\times 10^{-3}$ to $13.6 \times 10^{-3}$ to $8.0 \times 10^{-3}$ during the summer between ages 2 and 3 .

Seven eels $(41 \%)$ of the estuarine-resident group made periodic, sometimes seasonal, movements between the estuary and river mouth or river prior to entering the river at the time of capture. Brief excursions from high salinity waters to freshwater and return (Fig. 3E) are represented by the change in $\mathrm{Sr}: \mathrm{Ca}$ ratio of fish B2-13 from $9.0 \times 10^{-3}$ to $3.8 \times 10^{-3}$ to $10.4 \times$ $10^{-3}$ in the autumn between ages 1 and 2 , and by the change from $9.1 \times 10^{-3}$ to $4.3 \times 10^{-3}$ to $8.6 \times 10^{-3}$ during the spring at age-3.

About half (52\%) of the juvenile eels of Group 1 had otoliths that had not yet acquired the annulus for the current year. Most (77\%) age-1 eels showed plus growth or an annulus at the otolith edge while most $(75 \%)$ eels age-2 or older did not. For age-1 juvenile eels with an annulus evident, the mean otolith growth

Table 2. Anguilla rostrata. Life history behaviour patterns of juvenile and silver American eels as interpreted from the Sr:Ca ratios along a transect from otolith nucleus to edge and the location and timing of capture. The decision criterion for freshwater residence was an $\mathrm{Sr}: \mathrm{Ca}$ ratio $\leq 4.0 \times 10^{-3}$; for estuarine residence it was $\geq 5.0 \times 10^{-3}$

\begin{tabular}{|c|c|c|c|c|}
\hline \multirow{2}{*}{ Behaviour pattern } & \multicolumn{3}{|c|}{ Juvenile eels (\%) } & \multirow{2}{*}{$\begin{array}{c}\text { Silver eels (\%) } \\
\text { Group } 4 \\
(\mathrm{n}=64)\end{array}$} \\
\hline & $\begin{array}{l}\text { Group } 1 \\
(\mathrm{n}=29)\end{array}$ & $\begin{array}{c}\text { Group } 2 \\
(\mathrm{n}=8)\end{array}$ & $\begin{array}{l}\text { Group } 3 \\
(\mathrm{n}=19)\end{array}$ & \\
\hline Enter river as elvers & 41 & 13 & 89 & 75 \\
\hline Continuous freshwater residence & 17 & & 89 & 28 \\
\hline Irregular movement(s) between river and estuary & 24 & & & 47 \\
\hline Enter river as juveniles & 59 & 87 & 11 & 25 \\
\hline Continuous freshwater residence & & & 11 & 8 \\
\hline Irregular movement(s) between river and estuary & & & & 17 \\
\hline
\end{tabular}


between the elver check and annulus was $124.4 \mu \mathrm{m}$ ( $\mathrm{n}=9, \mathrm{SD}=41.26$, range 60 to $179 \mu \mathrm{m})$.

\section{Group 2}

The small (<70 mm), highly pigmented, early arriving juvenile eels of Group 2 had a mean length of $66.0 \mathrm{~mm}$ (range 62.0 to $69.8 \mathrm{~mm}$ ) and all were age-1 (Tables 1 \& 2). Six of the 8 juveniles examined had $\mathrm{Sr}$ :Ca ratios that averaged $2.22 \pm 1.15 \times 10^{-3}$ (range 0.5 to $3.7 \times 10^{-3}$ ) at the position of the annulus, indicating freshwater residence (eel B4-1, Fig. 4A). Two juveniles had overwintered in the estuary, as indicated by Sr:Ca ratios at the annulus of $6.9 \times 10^{-3}$ and $8.4 \times 10^{-3}$ (eel B4-10, Fig. 4A). When aged, eel B4-7 (Fig. 4B) showed very little growth after the elver check and no annulus; all other aged juveniles of this group showed slight plus growth beyond the annulus. The mean otolith growth between the elver check and first annulus was $68.7 \mu \mathrm{m}(\mathrm{n}=7, \mathrm{SD}=$ 22.4, range 49 to $110 \mu \mathrm{m}$ ) and was significantly



Fig. 4. Anguilla rostrata. Sr:Ca ratio transects along the otolith radius from core to edge of juvenile American eels less than $70 \mathrm{~mm}$ long and of pigmentation stage 8 caught at the mouth of the East River and illustrating various patterns of movement between estuarine and freshwaters: (A) entrance to the river as an elver and residence for 1 yr before being flushed to tidal waters during the spring freshet and estuarine residence for $1 \mathrm{yr}$ before entering the river; (B) highly pigmented elver; and $(\mathrm{C})$ juvenile eels caught $1.3 \mathrm{~km}$ upriver and showing estuarine residence and delayed entry for $1 \mathrm{yr}$ and rapid entrance and residence in the lower river for 1 yr before further upstream migration. The arrows mark the elver check and first annulus smaller than for the age-1 juveniles longer than $70 \mathrm{~mm}(t=-3.21$, df $=1,14, \mathrm{p}=0.006)$.

\section{Sr:Ca ratios in otoliths of juvenile eels of Group 3 from upstream}

Otoliths were examined from 19 juvenile eels of Group 3 (Tables 1 \& 2). All were age-1 or age-2 and ranged in length from 63.5 to $84.0 \mathrm{~mm}$ with a mean of $70.9 \mathrm{~mm}$. For 18 eels, the mean $\mathrm{Sr}$ :Ca ratio at the first annulus was $2.51 \times 10^{-3} \pm 0.46 \times 10^{-3}$ (range $0.7 \times 10^{-3}$ to $3.8 \times 10^{-3}$ ), indicating that they had remained $1 \mathrm{yr}$ in the lower river before migrating further upstream e.g. eel B3-18 (Fig. 4C). Eel B3-1 had an Sr:Ca ratio at the first annulus of $7.7 \times 10^{-3}$, indicating estuary residence for a year before entering the river and migrating upstream (Fig. 4C). Growth after the first annulus was evident in this eel, but there was no indication of a decline in $\mathrm{Sr}: \mathrm{Ca}$ ratio indicative of freshwater residence. Assuming that this juvenile entered the river at the peak of the juvenile run on May 22, then a change in environmental salinity may take more than $31 \mathrm{~d}$ to register in the otolith at mean daily water temperatures that increased from 13.8 to $23.0^{\circ} \mathrm{C}$ over the period of upstream migration. All $(\mathrm{n}=14)$ age-1 juvenile eels of this group possessed an annulus or plus growth, as did $80 \%$ of age- 2 juveniles.

\section{Sr:Ca ratios in otoliths of silver eels of Group 4 from upstream}

Otoliths of the 64 silver eels of Group 4 showed the same variety of temporal, life history patterns in the $\mathrm{Sr}$ :Ca ratio as the juvenile eels (Table 2, Fig. 5). The Sr:Ca ratio means at the primordium, metamorphosis check and elver check did not differ significantly from those for juvenile eels (all $\mathrm{p}>0.01$ ). Forty-eight of 64 eels (75\%) showed otolith $\mathrm{Sr}$ : Ca ratios declining to $\leq 4 \times 10^{-3}$ during the year of continental arrival, suggesting direct entry as elvers into the river (Table 2). For example, Sr:Ca ratios for eel Z87 (Fig. 5A) averaged $4.15 \times 10^{-3} \pm$ $0.42 \times 10^{-3}$ (range $3.1 \times 10^{-3}$ to $5.4 \times 10^{-3}$ ) between the elver check and the first annulus and $1.70 \times 10^{-3} \pm 0.17 \times$ $10^{-3}$ (range 0.0 to $3.5 \times 10^{-3}$ ) after the first annulus. Comparable values for eel Z68 were $5.57 \times 10^{-3} \pm 0.94 \times 10^{-3}$ (range $2.9 \times 10^{-3}$ to $7.0 \times 10^{-3}$ ) and $2.27 \times 10^{-3} \pm 0.21 \times$ $10^{-3}$ (range 0.0 to $4.8 \times 10^{-3}$, with 1 of 96 values exceeding 4.0).

Sixteen silver eels $(25 \%)$ had otolith $\mathrm{Sr}$ :Ca ratios that remained above $4 \times 10^{-3}$ for the first 1 or 2 yr (rarely more), indicating a period of residence in the estuary and delayed entry into the river (Table 2, Fig. 5A,D). The mean Sr:Ca ratios between the elver check and 
first annulus of juvenile eels that remained at least a year in the estuary before entering the river were slightly higher but not significantly different $(t=0.6$, $\mathrm{df}=1,18, \mathrm{p}=0.55$ ) from those of silver eels that behaved similarly (juvenile mean $6.41 \times 10^{-3}$, range $5.20 \times 10^{-3}$ to $7.46 \times 10^{-3}, \mathrm{n}=13$; silver eel mean $6.11 \times$ $10^{-3}$, range $4.15 \times 10^{-3}$ to $9.28 \times 10^{-3}, \mathrm{n}=7$ ).

After the initial entry to low salinity or freshwater, 2 additional behavioural groups were evident from the otoliths of the 64 silver eels examined: (1) continuous residence in freshwater (Table 2, Fig. 5A) and (2) irregular movements of variable duration (1 to $10 \mathrm{yr}$ ) between fresh and estuarine water of varying salinities (Table 2, Fig. 5B-E). Of the 48 eels that entered the river as elvers, $30(63 \%)$ showed $\mathrm{Sr}$ :Ca ratios greater than 5 after $1 \mathrm{yr}$ or more in the river, suggesting a return to estuarine waters. Of the 23 eels ( $36 \%$ of the total number of silver eels) that evidently remained in freshwater until silvering and migrating downstream, $18(78 \%)$ entered the river as elvers and $5(12 \%)$ entered as juveniles. Forty-one ( $64 \%$ of the total) silver eels showed a pattern of irregular movement between low and high salinity waters, of which 14 (34\%) returned to freshwater from 1 to 11 yr before silvering. The seasonal timing and direction of such movements could be interpreted as ranging from spring to fall or even winter, and upstream and downstream. In the final $50 \mu \mathrm{m}$ of the Sr:Ca transect, 26 (41\% of the total and $60 \%$ of the migratory group) of silver eel otoliths had mean $\mathrm{Sr}: \mathrm{Ca}$ ratios exceeding $4.5 \times 10^{-3}$, often greater than $6 \times 10^{-3}$ (Fig. 4D).

Male eels ranged in length between 326 and $412 \mathrm{~mm}$, and female eels ranged between 378 and $740 \mathrm{~mm}$. After adjusting for $2.0 \%$ shrinkage in length due to freezing and thawing, all female eels but one exceeded $400 \mathrm{~mm}$, the length that typically separates female from male American eels in this region (Krueger \& Oliveira 1997). Of the 64 silver eels whose otoliths were examined, 35 were male, 27 were female and 2 were of unknown (due to a data processing error) sex. The sex ratios of all behavioural groups were similar.

\section{Relative origin of silver eels}

Although most ( $75 \%$ ) silver eels from the East River derived from elvers that entered the river from the estuary shortly after continental arrival, $25 \%$ derived from juvenile eels that spent $1 \mathrm{yr}$ or more in the estuary before entering the river. The relative contribution to silver eel production by elvers and estuary-derived juvenile eels was estimated with the following assumptions: an annual elver run to the river of 850000 elvers (1996 to 2000 mean of 845000 elvers; Jessop in press), an average run of 750 juvenile eels from the estuary

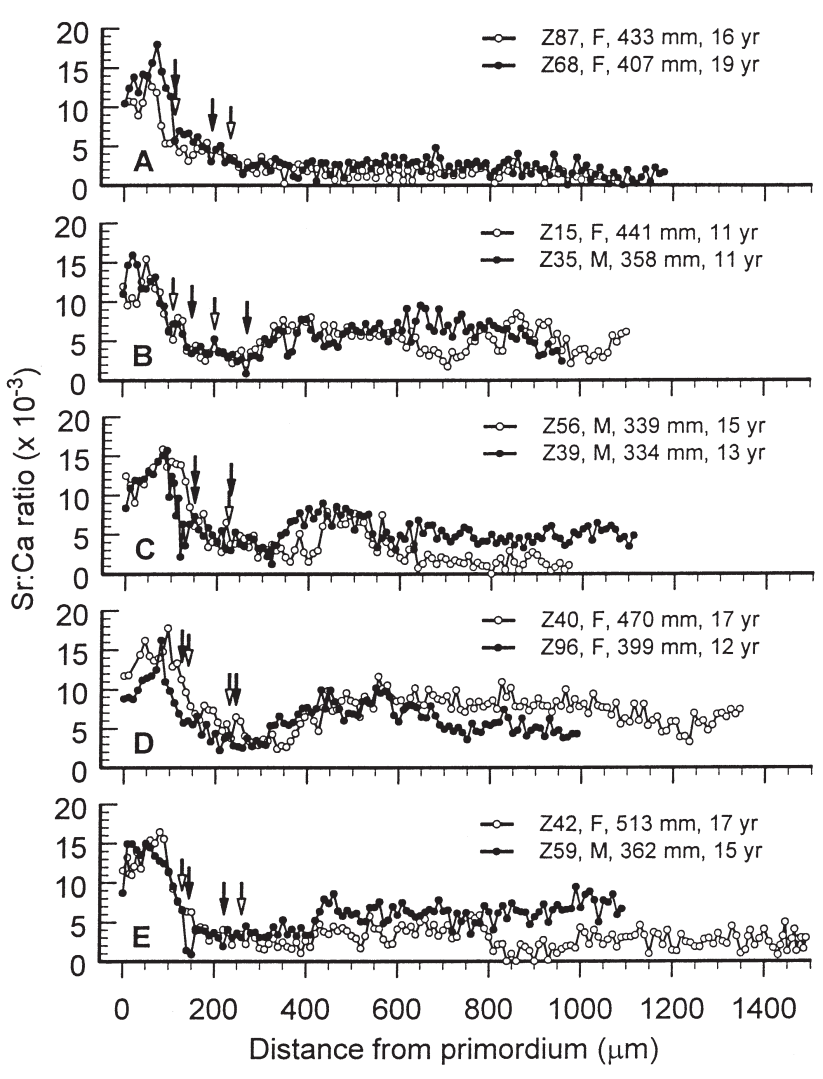

Fig. 5. Anguilla rostrata. Sr:Ca ratio transects along the otolith radius from core to edge of silver American eels from the East River and illustrating various patterns of movement: (A) estuarine residence for $1 \mathrm{yr}$ before entering and remaining in freshwater; (B) and (E) entering the river as an elver, then returning to the estuary for a period of residence before reentering the river; (C) and (D) varying periods of estuarine residence and return to freshwater or movement between areas of varying salinity. Note the high $\mathrm{Sr}$ :Ca ratios at the otolith edge in some fish. The arrows mark the elver check and first annulus. F: female; M: male

(1996 to 2000 mean of 750 juveniles) and an annual mortality rate of elvers in the river of $99.5 \%$ (Jessop 2000). The size of the annual run of silver eels is unknown. If 850000 elvers produce $75 \%$ of the silver eel run and 750 juveniles produce $25 \%$ of the run, then the relative production of silver eels was 380 times higher for juvenile eels that delayed entrance to the river than for elvers that entered the river directly.

\section{DISCUSSION}

\section{Migration patterns as inferred from otolith Sr:Ca ratios}

Juvenile American eels migrate seasonally between estuary and river (Smith \& Saunders 1955, Medcof 
1969), but detailed validation and quantitative studies are lacking. Temporal patterns in the Sr:Ca ratio along a radius in the otoliths of juvenile American eels migrating into and silver eels migrating from the East River were consistent with a variety of movement patterns among habitats of varying salinity (Secor et al. 1995, Tzeng 1996, Tzeng et al. 1997, Campana 1999, Secor \& Rooker 2000). The Sr:Ca ratios less than $4.0 \times$ $10^{-3}$ were consistent with residence in freshwater, and those greater than $5.0 \times 10^{-3}$ indicated estuarine residence. Occasional single values of the $\mathrm{Sr}$ :Ca ratio between $4.0 \times 10^{-3}$ and $5.0 \times 10^{-3}$ in a sequence of smaller or larger values perhaps resulted from minor analytical errors due to variation in the otolith crystalline structure, in surface preparation or in growth rate (Campana 1999), rather than from a change in habitat. In freshwater, reported Sr:Ca ratios have varied from $3 \times$ $10^{-3}$ to $4 \times 10^{-3}$ (Tzeng \& Tsai 1994) and $4 \times 10^{-3}$ (range $2 \times 10^{-3}$ to $7 \times 10^{-3}$ ) (Tzeng 1996) for Japanese eels to 3 $\times 10^{-3}$ for European eel (Tzeng et al. 1997). In estuarine waters, Sr:Ca ratios have varied from $7 \times 10^{-3}$ (range 4 $\times 10^{-3}$ to $9 \times 10^{-3}$ ) at $25 \%$ salinity for Japanese eel (Tzeng 1996) to $6 \times 10^{-3}$ for European eel in 23 to $25 \%$ salinity (Tzeng et al. 1997). A similar study by Kawakami et al. (1998) also reported Sr:Ca ratios in Japanese eel elvers that averaged about $4.5 \times 10^{-3}$ in freshwater and $8.2 \times 10^{-3}$ in full seawater. The minor differences among studies may result from differences in analytical methods, sampling sites and species.

The temporal patterns in movement comprised, in varying degree of frequency of occurrence, 4 of 5 hypothesised behavioural groups: (1) entrance to freshwater as an elver, (2) coastal or estuarine residence for 1 yr or more before entering freshwater as a juvenile, (3) continuous residence in freshwater until exiting as a silver eel, and (4) residence in freshwater for $1 \mathrm{yr}$ or more before migrating periodically and irregularly between river and estuary until exiting the river as a silver eel. Most (64\%) eels in the East River evidently engaged in periodic movement of varying duration between river and estuary. The proximate causes of such movements and their timing can only be speculated about. The sampling program was not designed to observe coastal or estuarine residents. Some elvers probably settled and remained in coastal waters or the estuary until sexual maturation. Such behaviour has been reported for European and Japanese eels (Tzeng et al. 2000, in press).

Not all elvers that enter the river migrate rapidly upriver. Age-1 and age-2 juvenile eels with Sr:Ca ratios indicative of residence in the lower $1.3 \mathrm{~km}$ of the river prior to further upstream migration were abundant in 2000. About 1200 juvenile eels were caught at the river mouth, yet 12200 juvenile eels were counted at the upriver site. The year 2000 was unusual in this respect; previous years had roughly similar numbers of juveniles at both river mouth and upriver sites. About $95 \%$ of the juvenile eels at both river mouth and upriver sites were less than $85 \mathrm{~mm}$ long, and 95\% of the juvenile eels caught upriver were age- 1 and had spent the previous year in the lower river (as represented by the Group 3 eel sample). Small numbers of elvers may, after entering the river, drop back to the estuary, where they may remain from days (Jessop 2000 ) to a year or more (this study). Some juvenile eels resident in the lower river may also briefly drop back to the upper estuary, most likely flushed out during the spring freshet, but others may remain there for an extended time.

The small (<70 mm TL), highly pigmented, early arriving eels were confirmed as slow growing age-1 juveniles, as had previously been hypothesised (Jessop 1998). These small juveniles were probably late arrivals during the preceding year because the mean length of elvers decreases over the run, and small quantities of elvers may continue to arrive in the estuary at least as late as mid-August (Jessop 1998). Of the 8 elver-sized juveniles examined, $75 \%$ had entered the river as elvers. Their capture below the falls at the river mouth indicates that they had been flushed downstream to the upper estuary during the spring runoff. One eel was highly pigmented but showed little growth and no annulus. It may have been a heavily pigmented elver, indicating that it may sometimes be difficult to separate elvers of pigment stage 7 from juveniles of pigment stage 8, or more likely a very slow growing juvenile that had arrived in the estuary very late in the previous year.

Annulus formation in the otoliths of juvenile eels is a progressive process that evidently begins before early May and is completed more quickly in faster growing age-1 eels than in slower growing age-2 eels, for which annulus completion may take until mid-June or later. Similarly, a change in the otolith $\mathrm{Sr}$ :Ca ratio in response to a change in habitat salinity may take over $30 \mathrm{~d}$ to become evident, even in relatively fast growing young eels and perhaps much longer in slower growing, older eels such as silver eels.

\section{Hypotheses to explain the $\mathrm{Sr}$ :Ca ratio variability in silver eel otoliths}

Once in the river, about $36 \%$ of eels remained there until migrating downstream as silver eels. Although most $(64 \%)$ silver eels appeared to have made irregular movements of variable duration (1 to $10 \mathrm{yr}$ ) between fresh and estuarine waters, about $34 \%$ of these freshwater-estuarine migrants evidently returned to the river several years prior to silvering. Sharp changes 
in $\mathrm{Sr}$ :Ca ratios to below $4.0 \times 10^{-3}$ or above $5.0 \times 10^{-3}$ were readily interpreted, but extended fluctuations about these values were problematic. They perhaps reflected a series of quick movements between estuary and river or residence in the river-influenced upper estuary, in conjunction with the physiological lag in incorporating into the otolith the evidence of a habitat shift. However, it is puzzling why $41 \%$ of the silver eel total had Sr:Ca ratios greater than $4.5 \times 10^{-3}$ at the otolith edge, which suggests estuarine residence, when they were collected in freshwater $1.3 \mathrm{~km}$ upstream from the river mouth and migrating downstream. Several hypotheses can be proposed: (1) the results are an artefact of otolith preparation and analysis; (2) shortly, perhaps a year, before silvering, estuarine-resident eels re-entered the river for a brief (no evidence of freshwater residence was yet evident in the otoliths) period of freshwater residence before migrating downstream as silver eels; and (3) once in the river, the eels had remained there and the variation in $\mathrm{Sr}$ :Ca ratio was due to varying environmental conditions in the river, such as low $\mathrm{pH}$, the annual liming of one tributary of the river between 1986 and 1996 or variable annual growth rates.

The hypothesis that the high Sr:Ca ratios at the edge of some silver eel otoliths is an artefact of otolith preparation and analysis rather than a reflection of the most recent environmental history of the eel is perhaps the most plausible. The transect of $\mathrm{Sr}$ :Ca ratios along the otolith radius may not always reach the exact edge of the otolith, the radius analysed may not be the longest one, with consequent compression of the temporal pattern of otolith composition at the edge, and the polished plane of the otolith may be slightly rounded at the edge. If the final $\mathrm{Sr}$ :Ca ratio is not exactly at the otolith edge, the evidence of recent habitat change may be absent. Given that otolith growth is much reduced at older ages, the time to incorporate $\mathrm{Sr}$ and Ca may be increased and slower growth may magnify Sr levels (Kalish 1989). If it takes about a month to incorporate evidence of habitat change in the otoliths of fast growing juvenile eels, it may take much longer in slow growing silver eels. If Sr persists in the bloodstream for a while after a move from estuary to river, $\mathrm{Sr}$ :Ca ratios intermediate between those in freshwater and estuary may arise (Howland et al. 2001). The sharp decline in otolith $\mathrm{Sr}$ :Ca ratio spot values near the otolith edge in most silver eels with mean ratios between $4.50 \times 10^{-3}$ and $4.99 \times 10^{-3}$ supports the interpretation of a lag in the manifestation of habitat change within the otolith. The time period represented in the otolith chronology by a microprobe spot of a given size also tends to increase as the otolith edge is approached, blurring the determination of the time at which a habitat shift occurred. Consequently, the final readings along the outermost edge of the $\mathrm{Sr}$ :Ca ratio transect may not reflect the environmental history of the eel at the time of capture, particularly for those with a history of recent migration between river and estuary. Perhaps as much as a year or two may be obscured in this manner.

There is no obvious biological reason for estuarineresident maturing eels to enter freshwater for a relatively brief period prior to silvering and beginning the spawning migration. Although the timing of such a return to the river is uncertain due to the potential problems associated with estimating the $\mathrm{Sr}$ :Ca ratio near the otolith edge, even if periods up to 1 or even $2 \mathrm{yr}$ are obscured, the question remains unanswered as to why some estuarine-resident eels return to the river a relatively short time prior to silvering. There is no evidence that estuarine-resident eels such as those in the Baltic Sea or those in Mikawa Bay, Japan, enter freshwater just before migration (Tzeng et al. 2000, in press). Whether some river-to-estuary migrants remain in the estuary during silvering is unknown.

The hypothesis that the silver eels remained in the river as juveniles and that freshwater environmental conditions, such as low $\mathrm{pH}$ and the liming of one tributary of the river, may account for the varying annual patterns of low and high $\mathrm{Sr}$ :Ca ratio depends on the $\mathrm{Sr}$ and $\mathrm{Ca}$ concentrations in the calcite, their availability relative to background environmental levels, and the effect of low or varying $\mathrm{pH}$ on element uptake. The effect of low or changing $\mathrm{pH}$ on the uptake of $\mathrm{Sr}$ and $\mathrm{Ca}$ from the environment is poorly understood (Campana 1999). Ambient concentrations of $\mathrm{Sr}$ and $\mathrm{Ca}$ are reflected in otolith composition, with the molar ratio of $\mathrm{Sr}$ :Ca more relevant to relative rates of uptake in fish than are the absolute concentrations (Campana 1999). Although the concentration of $\mathrm{Sr}$ is about 100 times higher in salt water than in freshwater, the molar ratios differ by about 4.8 times $\left(8.6 \times 10^{-3}\right.$ vs $\left.1.8 \times 10^{-3}\right)$. The molar ratio of $\mathrm{Sr}$ :Ca in the calcite was $0.05 \times 10^{-3}$ ( T . Goodwin, Nova Scotia Department of Natural Resources, Halifax, pers. comm.). Thus, liming of the East Branch greatly increased the available Ca but not Sr. The increased availability of $\mathrm{Ca}$ in the limed area may also have had little effect because otolith Ca does not, under normal conditions, respond to variability in water concentrations (Campana 1999). The high Sr and low $\mathrm{Ca}$ concentrations in the river water reflect the relatively high $\mathrm{Sr}$ (till sample means of 69 to $81 \mathrm{ppm}$ and bedrock means of 22 to $104 \mathrm{ppm}$ ) and low Ca concentrations in the granite bedrock and overlying tills of the watershed (Graves et al. 1988). Five years after the liming ceased, the molar ratio of $\mathrm{Sr}: \mathrm{Ca}$ in the water near the river mouth was $2.5 \times 10^{-3}$ or 53 times that in the calcite, and the Ca concentration was similar to that in the unlimed Canaan River (mean Ca of $930 \mathrm{\mu g} \mathrm{l}^{-1}$ in the 
Canaan River versus $900 \mu \mathrm{g} \mathrm{l}^{-1}$ at the river mouth). Thus, liming of the East River is unlikely to account for the variable Sr:Ca ratios observed in some silver eels or for the high Sr:Ca ratios at the otolith edge in others.

The timing of the observed movement of small, young juvenile eels into the East River during spring was readily interpretable from the $\mathrm{Sr}$ :Ca ratio patterns along a transect from nucleus to edge in their otoliths. The silver eel otolith data indicated that larger, older juvenile eels move between estuary and river, as was noted by Smith \& Saunders (1955) and Medcoff (1969), who reported movements downstream during the spring and upstream during the autumn. However, the timing of such movements, as interpreted from the silver eel otoliths, is more variable than previously reported. A temporal lag in incorporating evidence of habitat change in the otolith, slow growth in older eels or inaccuracies in determining annulus position relative to $\mathrm{Sr}$ :Ca ratios may affect the reliability of interpretations of silver eel movements from otoliths.

\section{Relative origin of silver eels}

Groups of fish exhibiting different migration behaviours or habitat use within a genetic population have been termed contingents (Clark 1968, Secor 1999). Contingent behaviours may result from early life decisions about the energetic trade-offs between maintenance and growth in relation to mortality. Diverse contingent migratory tactics reflect population-specific reaction norms in relation to ontogeny, population density and habitat distribution. The variety of migratory behaviours observed in American, European and Japanese eels is consistent with contingent theory. Such contingents likely reflect phenotypic plasticity in eel behaviour and habitat selection (Helfman et al. 1987, Vøllestad 1992) in response to the wide variety of habitats encountered by eel species throughout their wide geographic ranges.

A significant contribution to the production of silver eels in the river by juvenile eels that migrated into the river after 1 to $4 \mathrm{yr}$ in the estuary emphasises the importance of different contingent migratory behaviours in the adaptation by American eels to the variety of environments that they inhabit. A production of silver eels by juvenile eels that had entered the river after $1 \mathrm{yr}$ or more in the estuary that was about 380 times higher than for elvers that had entered directly into the river reflects the high mortality rate of elvers in the river (Jessop 2000). Although most elvers are believed to enter the river rather than remain in the estuary, the mortality rate of elvers remaining in the estuary may be lower than in the river.
This study has illustrated a variety of migratory behaviours by American eels, behaviours that require consideration when estimating and utilising data on population size and structure and incorporating such data into models of eel life history, mortality and production.

Acknowledgements. We thank K. Marshall, J. Orser, D. Schnare, D. Sutherland and S. Ratelle for their assistance in various aspects of the collection and processing of the eel samples. The National Science Council, Republic of China, provided financial support for the otolith analysis through Grant Number NSC-89-2313-B002-077.

\section{LITERATURE CITED}

Arai T, Otake T, Tsukamoto K (2000) Timing of metamorphosis and larval segregation of the Atlantic eels Anguilla rostrata and A. Anguilla, as revealed by otolith microstructure and microchemistry. Mar Biol 137:39-45

Campana SE (1999) Chemistry and composition of fish otoliths: pathways, mechanisms and applications. Mar Ecol Prog Ser 188:263-297

Cheng PW, Tzeng WN (1996) Timing of metamorphosis and estuarine arrival across the dispersal range of the Japanese eel Anguilla japonica. Mar Ecol Prog Ser 131:87-96

Clark J (1968) Seasonal movements of striped bass contingents of Long Island Sound and the New York Bight. Trans Am Fish Soc 123:950-963

Elie P, Lecomte-Finiger R, Cantrelle I, Charon N (1982) Définition des limites des différentes stades pigmentaires durant la phase civelle d'Anguilla anguilla L. (Poisson téléostéen anguilliforme). Vie Milieu 32:149-157

Goldstein JI, Newbury DE, Echlin P, Joy DC, Fiori C, Lifshin E (1984) Scanning electron microscopy and x-ray microanalysis - a text for biologists, materials scientists, and geologists. Plenum Press, New York

Graves RM, MacDonald MA, Finck PW, Boner FJ (1988) A comparison of the clast composition and geochemistry of granite tills to underlying bedrock in the Halifax pluton, central Nova Scotia. In: Prospecting in areas of glaciated terrain-1988. Canadian Institute of Mining and Metallurgy, Montreal, p 21-39

Gunn JS, Harrowfield IR, Proctor CH, Thresher RE (1992) Electron microprobe analysis of fish otoliths - evaluation of techniques for studying age and stock discrimination. J Exp Mar Biol Ecol 158:1-36

Haro AJ, Krueger WH (1988) Pigmentation, size and migration of elvers (Anguilla rostrata (LeSueur)) in a coastal Rhode Island stream. Can J Zool 66:2528-2533

Helfman GS, Facey DE, Hales LS Jr, Bozeman EL Jr (1987) Reproductive ecology of the American eel. Am Fish Soc Symp 1:42-56

Howland KL, Tonn WM, Babaluk JA, Tallman RF (2001) Identification of freshwater and anadromous inconnu in the Mackenzie River system by analysis of otolith strontium. Trans Am Fish Soc 130:725-741

Jessop BM (1987) Migrating American eels in Nova Scotia. Trans Am Fish Soc 116:161-170

Jessop BM (1997) The biological characteristics of, and efficiency of dip-net fishing for, American eel elvers in the East River, Chester, Nova Scotia, Doc 97-01. Department of Fisheries and Oceans, Halifax 
Jessop BM (1998) Geographic and seasonal variation in biological characteristics of American eel elvers in the Bay of Fundy area and on the Atlantic coast of Nova Scotia. Can J Zool 76:2172-2185

Jessop BM (2000) Estimates of population size and instream mortality rate of American eel elvers in a Nova Scotia river. Trans Am Fish Soc 129:514-526

Jessop BM (in press) Annual and seasonal variability in the size and biological characteristics of the runs of American eel elvers to two Nova Scotia rivers. In: Dixon DA (ed) Biology, management, and protection for catadromous eels. Am Fish Soc Symp 33

Kalish JM (1989) Otolith microchemistry: validation of the effects of physiology, age and environment on otolith composition. J Exp Mar Biol Ecol 132:151-178

Kawakami Y and 6 others (1998) Factors influencing otolith strontium/calcium ratios in Anguilla japonica elvers. Environ Biol Fish 52:299-303

Krueger WH, Oliveira K (1997) Sex, size, and gonad morphology of silver American eels Anguilla rostrata. Copeia 1997:415-420

Medcof JC (1969) Fishermen's reports of freshwater and saltwater migrations of Nova Scotia eels (Anguilla rostrata). Can Field Nat 83:132-138

Oliveira K (1996) Field validation of annular growth rings in the American eel, Anguilla rostrata, using tetracyclinemarked otoliths. Fish Bull 94:186-189

Oliveira K (1999) Life history characteristics and strategies of the American eel, Anguilla rostrata. Can J Fish Aquat Sci 56:795-802

Otake T, Ishii T, Nakahara M, Nakamura R (1994) Drastic changes in otolith strontium/calcium ratios in leptocephali and glass eels of Japanese eel Anguilla japonica. Mar Ecol Prog Ser 112:189-193

Proctor CH, Thresher RE (1998) Effects of specimen handling and otolith preparation on concentration of elements in fish otoliths. Mar Biol 131:681-694

Secor DH (1999) Specifying divergent migrations in the concept of stock: the contingent hypothesis. Fish Res 43: $13-34$

Secor DH, Rooker JR (2000) Is otolith strontium a useful scalar of life cycles in estuarine fishes? Fish Res 46:359-371

Secor DH, Henderson-Arzapalo A, Piccoli PM (1995) Can otolith microchemistry chart patterns of migration and habitat utilization in anadromous fishes. J Exp Mar Biol Ecol 192:15-33

Shiao JC, Tzeng WN, Collins A, Jellyman DJ (2001) Dispersal pattern of glass eel stage of Anguilla australis revealed by otolith growth increments. Mar Ecol Prog Ser 219:241-250

Smith WM, Saunders JW (1955) The American eel in certain fresh waters of the Maritime provinces of Canada. J Fish Res Board Can 12:238-269

Editorial responsibility: Kenneth Sherman (Contributing Editor), Narragansett, Rhode Island, USA
Tesch FW (1977) The eel: biology and management of anguillid eels. Chapman \& Hall, London

Tsukamoto K, Nakai I, Tesch WV (1998) Do all freshwater eels migrate? Nature 396:635-636

Tzeng WN (1996) Effects of salinity and ontogenetic movements on strontium:calcium ratios in the otoliths of the Japanese eel, Anguilla japonica Temminck and Schlegel. J Exp Mar Biol Ecol 199:111-122

Tzeng WN, Tsai YC (1994) Changes in otolith microchemistry of the Japanese eel, Anguilla japonica, during its migration from the ocean to the rivers of Taiwan. J Fish Biol 45: 671-683

Tzeng WN, Wu HF, Wickström H (1994) Scanning electron microscope analysis of annulus microstructure in otolith of European eel, Anguilla anguilla. J Fish Biol 45:479-492

Tzeng WN, Severin KP, Wickström H (1997) Use of otolith microchemistry to investigate the environmental history of European eel Anguilla anguilla. Mar Ecol Prog Ser 149: $73-81$

Tzeng WN, Severin KP, Wickström H, Wang CH (1999) Strontium bands in relation to age marks in otoliths of European eel Anguilla anguilla. Zool Stud 38:452-457

Tzeng WN, Wang CH, Wickström H, Reizenstein M (2000) Occurrence of the semi-catadromous European eel Anguilla anguilla in the Baltic Sea. Mar Biol 137:93-98

Tzeng WN, Shiao JC, Yamada Y, Oka HP (in press) Life history patterns of Japanese eel Anguilla japonica in Mikawa Bay, Japan. In: Dixon DA (ed) Biology, management, and protection for catadromous eels. Am Fish Soc Symp 33

Vøllestad LA (1992) Geographic variation in age and length at metamorphosis of maturing European eel: environmental effects and phenotypic plasticity. J Anim Ecol 61:41-48

Wang $\mathrm{CH}$, Tzeng WN (1998) Interpretation of geographic variation in size of American eel Anguilla rostrata elvers on the Atlantic coast of North America using their life history and otolith ageing. Mar Ecol Prog Ser 168:35-43

Wang CH, Tzeng WN (2000) The timing of metamorphosis and growth rates of American and European leptocephali: a mechanism of larval segregative migration. Fish Res 46 : 191-205

Watt WD, White WJ (1992) Creating a de-acidified Atlantic salmon refuge in the East River, Nova Scotia. In: Beattie BL (ed) Report for 1991 from the Atlantic Region Monitoring and Effects Working Group. Environment Canada, Bedford, p 148-164

Watt WD, Scott CD, Mandell P (1995) Water chemistry data from a monitoring program designed to detect changes in the long range transport of acidic pollutants into Nova Scotia's acidified Atlantic salmon rivers. Can Data Rep Fish Aquat Sci 972

Wickstrom H (1986) Studies on the European eel by the Institute of Freshwater Research 1977-85. Inf Sötvattenslab 13

Submitted: April 20, 2001; Accepted: November 29, 2001

Proofs received from author(s): April 24, 2002 